\title{
PENDIDIKAN ILMU KESEJAHTERAAN SOSIAL BAGI PEKERJA SOSIAL
}

\author{
Oleh; \\ Martha Sintaully Agustine, Risna Risnawaty, \& Meillanny Budiarti S.
}

Email: marthasintaully@yahoo.com

\begin{abstract}
Abstrak
Realitasnya di Indonesia, masih banyak kalangan yang mengatakan bahwa pekerjaan sosial dapat dilakukan oleh siapa saja tanpa ilmu dan pendidikan. Kegamangan profesi pekerjaan sosial di tengah masyarakat tampak jelas ketika lulusan pendidikan pekerjaan sosial tidak mendapatkan pekerjaan yang layak sesuai dengan ilmunya. Masalah ini disebabkan dari masih kurangnya pemahaman mengenai profesi pekerjaan sosial oleh masyarakat sehingga keberadaan pendidikan pekerjaan sosial menjadi kurang jelas arahnya. Untuk mendapatkan pemahaman yang tepat, sebelumnya kita perlu membedakan antara kesejahteraan sosial dan pekerjaan sosial. Kesejahteraan sosial adalah semua aktivitas intervensi sosial untuk meningkatkan keberfungsian sosial umat manusia. Sedangkan pekerjaan sosial adalah profesional yang menerima pelayanan kesejahteraan sosial. Jadi, pekerjaan sosial lebih berkaitan dengan profesi pekerjaan dan kesejahteraan sosial adalah ilmu yang membidanginya. Ini sama halnya dengan dokter dokter dengan ilmu kedokteran, guru dengan pendidikan, psikolog dengan psikologi dan seterusnya. Seperti halnya dokter, ketika tindakan medis dilakukan oleh seseorang yang bukan berlatar belakang pendidikan kedokteran maka kemungkinan terjadinya malpraktik sangat besar. Pekerja sosial pun demikian, orang yang berlatar belakang pendidikan ilmu kesejahteraan sosial secara konsep pasti lebih matang dibandingkan dengan mereka yang tidak berlatar belakang pendidikan ilmu kesejahteraan sosial, ketika suatu intervensi dilakukan oleh orang yang tidak ahli dalam bidangnya maka akan menimbulkan konsep yang salah dan berujung pada praktik yang tidak benar. Untuk itu penting diperhatikannya latar belakang ilmu yang membidangi suatu profesi
\end{abstract}

\section{PENDAHULUAN}

Akar sejarah dari bidang ilmu sosial dan kesejahteraan sosial seringkali dikaitkan pada kondisi eropa abad ke 13-18 yang mencangkup tiga penerimaan bantuan: (1) orang-orang miskin yang kondisi fisiknya masih kuat, (2) orang-orang miskin yang kondisi fisiknya buruk, dan (3) anak-anak yang masih tergantung pada orang yang lebih mapan.

Berdasarkan penjelasan tersebut maka terlihat bahwa pekerjaan sosial sebagai suatu ilmu berawal dari perkembangan pemikiran dari para philantrophis yang sekaligus juga merupakan relawan. Aktivitas volunteerisme tetap dapat terlihat jejaknya dalam perkembangan bidang pekerjaan sosial meskipun bidang pekerjaan sosial itu sendiri sudah jauh meluas bila dibandingkan dengan bidang kerelawanan.

Pekerjaan sosial sebagai suatu ilmu memfokuskan intervensinya pada proses interaksi antara manusia dengan lingkungannya dengan menggunakan teoriteori prilaku manusia dan sistem sosial, guna meningkatkan taraf hidup masyarakat.

Kemudian, ilmu kesejahteraan sosial merupakan perkembangan pemikiran dari disiplin pekerjaan sosial. Akan tetapi, pada disiplin pekerjaan sosial pembahasan lebih banyak dipengaruhi oleh disiplin psikologi dan kemudian dilengkapi dengan sedikit disiplin 
sosiologi. Ilmu kesejahteraan osial itu sendiri pada dasarnya merupakan ilmu terapan. Kajian baik secara teoritis maupun metdologis terhadap upaya-upata untuk meningkatkan kualitas hidup suatu masyarakat.

Implikasinya terhadap dunia pendidikan adalah ilmu kesejahteraan sosial menjadi ilmu yang membidangi profesi pekerjaan sosial. Salah satu fungsi dari disiplin ilmu kesejahteraan sosial antara lain adalah mendidik ataupun melatih pekerja sosial.

Sebagai suatu disiplin keilmuan, konsep kesejahteraan sosial dipandang sebagai sebuah bidang kajian keilmuan yang ditujukan untuk mengkaji, mengantisipasi keadaan dan perubahan kehidupan sosial, serta merumuskan alternatif tindakan guna menciptakan situasi kehidupan sosial yang kondusif bagi upaya masyarakat dalam memenuhi kebutuhan-kebutuhan hidupnya sendiri. Sudut kajian yang membedakan bidang kesejahteraan sosial dari bidang-bidang keilmuan lainnya terletak pada konsep sosial, yaitu pengertian dasarnya adalah hubungan (interaksi ) antar manusia.

\section{KAJIAN PUSTAKA:}

Perdebatan apakah pekerjaan sosial merupakan suatu profesi atau bukan, bidang profesional atau bukan, pada dasarnya telah lama ditinggalkan. Dewasa ini, telah diakui bahwa pekerjaan sosial merupakan suatu profesi pertolongan, oleh sebab itu pekerjaan sosial merupakan suatu bidang profesional. Sehubungan dengan pernyataan bahwa pekerjaan sosial merupakan bidang profesional maka pendidikan dan latihannya pun harus bersifat profesional. Sifat profesional tersebut tercermin melalui sistem administrasi pendidikannya dan juga pengelolaan pendidikan khususnya proses belajar dan pembelajaran.

Terdapat beberapa hal yang menjadi landasan dalam pengelolaan pendidikan profesionalpekerjaan sosial yaitu:
- Tujuan pendidikan pekerjaan sosial adalah untuk menyiapkan pekerja sosial profesional yang memiliki kompetensi dan komitmen terhadap praktek termasuk pelayanan sosial

- Pendidikan pekerjaan sosial adalah berdasarkan kerangka pengetahuan, nilainilai dan keterampilan profesional yang khusus.

- Pendidikan pekerjaan sosial diselenggarakan dari jenjang pendidikan sarjana (S1), Master (S2), dan Doktor (S3)

- Program pendidikan pekerjaan sosialmemelihara kedekatan, hubungan timbal balik, dan hubungan dengan para praktisi pekerjaan sosial dengan kelompok dan organisasi untuk memajukan, memberikan, atau mencari pengaruh dalam pembuatan kebijakan dan pelayanan pekerjaan sosial.

- Efektifitas suatu profesi tergantung pada keterlibatan aktif anggota dalam profesi tersebut dalam pendidikan berkelanjutan. Program pendidikan pekerjaan sosial bertujuan untuk memajukan pengembangan profesional yang berkelanjutan kepada mahasiswa dan juga staf pengajar.

- $\quad$ Program pendidikan pekerjaan sosial yang efektif mengakui saling ketergantungan antar negara dan keperluan untuk kerjasama profesional di seluruh dunia.

- Program pendidikan pekerjaan sosial berasumsi bahwa suatu peranan kepemimpinan yang berkaitan dengan profesi dimanifestasikan dalam bentuk penyajian kurikulum yang mengedepankan suatu yang baru dan perubahan dasar pengetahuan pekerjaan sosial dari disiplin disiplin lain yang mendukung.

Berdasarkan penjelasan tersebut maka tujuan pendidikan pekerjaan sosial adalah memungkinkan seseorang dapat mengintegrasikan pengetahuan, nilai-nilai, dan 
keterampilan profesi pekerjaan sosial ke dalam kompetensi praktek.

Pemerintah melakukan upaya sertifikasi terhadap pekerja sosial profesional dan tenaga kesejahteraan sosial untuk meningkatkan pelayanan kesejahteraan sosial. Idealnya, seluruh pekerja sosial profesional menurut Peraturan Mentri Nomor: 108/HUK/2009 tentang sertifikasi bagi pekerja sosial profesional dan tenaga kesejahteraan sosial harus mengikuti sertifikasi dengan syarat dan ketentuan sebagai berikut; (1) berpendidikan sekurang-kurangnya Sarjana/Diploma IV pekerjaan sosial/kesejahteraan sosial, (2) berpengalaman kerja sekurang-kurangnya 2 tahun dalam melaksanakan praktik pekerjaan sosial dan penyelenggaraan kesejahteraan sosial, (3) telah mengikuti pelatihan di bidang pekerjaan sosial dengan jumlah keseluruhan. minimal 60 jam latihan. Akan tetapi, karena terbatasnya pekerja sosial profesional di Indonesia maka lembaga yang membutuhkan pekerja sosial profesional di Indonesia maka tidak jarang lembaga yang membutuhkan pekerja sosial, juga memperkerjakan pekerja sosial yang bukan dari lulusan ilmu kesejahteraan sosial.

Fakta di lapangan bahwa tidak semua pekerja sosial berlatar belakang pendidikan ilmu kesejahteraan sosial seperti yang pemerintah inginkan menimbulkan pertanyaan tersendiri mengenai apakah hal tersebut mempengaruhi upaya kesejahteraan sosial yang dilakukan atau tidak. Karena sebagai ilustrasi dapat digambarkan sebagaimana dokter dan ilmu kedokteran. Tindakan medis harus dilakukan oleh seseorang yang kita sebut dokter dimana ia memiliki keahlian dalam bidang ilmu kedokteran. Keahlian tersebut di dapatkan melalui pendidikan kedokteran. Ketika suatu tindakan medis dilakukan oleh seseorang yang tidak memiliki latar belakang pendidikan kedokteran maka resiko terjadinya mal praktik menjadi sangat lah besar.

Demikian pula dengan profesi pekerja sosial. Suatu intervensi khususnya pada masalah sosial membutuhkan penanganan dari seorang ahlinya yang kita sebut sebagai pekerja sosial. Keahlian tersebut diperoleh melalui pendidikan ilmu kesejahteraan sosial karena ilmu tersebut lah yang membidangi profesi pekerja sosial. Ketika suatu intervensi dilakukan oleh orang yang tidak ahli dalam bidangnya maka akan menimbulkan konsep yang salah dan berujung pada praktik yang tidak benar. Untuk itu penting diperhatikannya latar belakang ilmu yang membidangi suatu profesi.

\section{KESIMPULAN}

Harus diakui bahwa dibandingkan dengan profesi lain, pekerja sosial di Indonesia masih berkutat pada persoalan pencarian identitas, termasuk perumusan bidang garapan, kompetensi, dan komitmen pertolongan.

Persoalan ini walaupun menjenuhkan namun masih harus didiskusikan lebih dalam lagi. Kunci penekanan pekerja sosial profesional adalah pada bekal pengetahuan dan keterampilan yang didapat dari pendidikan. Disinilah peran kesejahteraan sosial dalam rangka menciptakan pekerja sosial profesional. Di Indonesia, peran-peran yang semestinya dimainkan oleh pekerja sosial profesional tersebut kerap dilakukan oleh orang lain yang tidak berlatar belakang pendidikan kesejahteraan sosial atau pekerjaan sosial. Hal tersebut sangat di sayangkan, sebab mengaburkan pandangan mengenai profesi pekerja sosial.

Daftar Pustaka :

(1) Jurnal

Suharto, Edi. 2010. Pendidikan dan Praktek Pekerjaan Sosial di Indonesia. Bandung: STKS Press

Fahrudin, Adi. 2010. Standar Global Pendidikan Pekerjaan Sosial dan Kritik Terhadap Kurikulum Pendidikan Pekerjaan Sosial di Indonesia. Bandung 
Cahyono, Edy. 2012. Kesejahteraan Sosial, Pekerjaan Sosial, dan Pekerja Sosial 